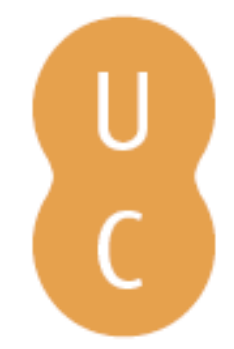

\title{
pommalina
}

\section{Antígona 1-11-14 del Bajo Flores: versión libre sobre Antígona de Sófocles de Marcelo Marán: una lectura}

\author{
Autor(es): $\quad$ Saravia, María Inés \\ Publicado por: Imprensa da Universidade de Coimbra; Annablume \\ URL \\ persistente: URI:http://hdl.handle.net/10316.2/40927 \\ DOI: $\quad$ DOI:https://doi.org/10.14195/978-989-26-1298-0_21 \\ Accessed : $\quad$ 26-Apr-2023 16:27:40
}

A navegação consulta e descarregamento dos títulos inseridos nas Bibliotecas Digitais UC Digitalis, UC Pombalina e UC Impactum, pressupõem a aceitação plena e sem reservas dos Termos e Condições de Uso destas Bibliotecas Digitais, disponíveis em https://digitalis.uc.pt/pt-pt/termos.

Conforme exposto nos referidos Termos e Condições de Uso, o descarregamento de títulos de acesso restrito requer uma licença válida de autorização devendo o utilizador aceder ao(s) documento(s) a partir de um endereço de IP da instituição detentora da supramencionada licença.

Ao utilizador é apenas permitido o descarregamento para uso pessoal, pelo que o emprego do(s) título(s) descarregado(s) para outro fim, designadamente comercial, carece de autorização do respetivo autor ou editor da obra.

Na medida em que todas as obras da UC Digitalis se encontram protegidas pelo Código do Direito de Autor e Direitos Conexos e demais legislação aplicável, toda a cópia, parcial ou total, deste documento, nos casos em que é legalmente admitida, deverá conter ou fazer-se acompanhar por este aviso.

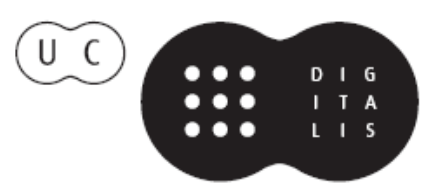




\section{O Livro do Tempo: \\ Escritas e reescritas}

\section{Teatro Greco-Latino e sua recepção II}

Maria de Fátima Silva, Maria do Céu

Fialho \& José Luís Brandão (coords.)

IMPRENSA DA UNIVERSIDADE DE COIMBRA 


\title{
Antígona 1-11-14 del Bajo Flores. Versión libre sobre Antígona de Sófocles de Marcelo Marán. Una lectura (Antigone 1-11-14 of Bajo Flores. A free version by Marcelo Marán of Sophocles' Antigone)
}

\author{
María Inés SAravia (marinesaravia@yahoo.com.ar) \\ Universidad Nacional de La Plata- Conicet
}

\begin{abstract}
Resumen - En la Antígona 1-11-14 del Bajo Flores, M. Marán ubica el conflicto de los Labdácidas en la villa del Bajo Flores (Buenos Aires), para exponer el problema de la comercialización de la droga. Se analizan algunas confluencias con la obra de Sófocles, Anouilh y las estéticas modernas.
\end{abstract}

Palabras clave - Antígona, Bajo Flores, Marán, Sófocles, Anouilh.

Aвstract - M. Maran places the conflict of the Labdakos house in the village of Bajo Flores (Buenos Aires), to expose the problem of drug marketing. Some confluences with Sophocles, Anouilh and modern aesthetics are analysed.

KeYwords - Antigone, Bajo Flores, Marán, Sophocles, Anouilh.

Marcelo Marán, autor marplatense, estrenó esta obra en La Plata en 2014, prosiguiendo con una lista proficua de diversas Antígonas que siguen interpelándonos, como lo hace la Antígona de L. Marechal, de A. Zavalía, de G. Gambaro, de D. Cureses, J. C. Gené, la francesa Antigone Voilée de François Ost (2004) y Usted está aqui, Antigone (2009), pieza de la mejicana Bárbara Colio y ${ }^{1}$, entre las últimas obras de esta extensa lista, menciono especialmente la Antígona 1-11-14 de Marcelo Marán y la Antígona Libre de Luis Favero, ambas escritas en 2014 e inéditas. La primera, a la que me dedicaré, plantea el conflicto tebano en la villa miseria del Bajo Flores (Buenos Aires) y enfoca el problema de la comercialización de la droga en el conurbano, especialmente el paco, con fuertes connotaciones de la política y el narcotráfico ${ }^{2}$. Aparecen personajes como el Cura Villero, un homenaje al padre Mugica, además de los transas y los sicarios. El impacto visual que producen los cadáveres desde el primer momento, además de la referencia al sol de Tebas en la párodos (cuando Hemón espera el amanecer alrededor del fuego) y el primer estásimo, en la voz del Cura, remiten con nitidez a la obra de Sófocles.

${ }^{1}$ Cf. Nelli 2012: 55-65. En verdad, la totalidad del vol. 59 de Romance Quarterly fue dedicado a estudios sobre Medeas y Antígonas modernas.

${ }^{2}$ Cf. Dubatti 2014 (online) quien afirma: "El castigo de Creonte a Polinices implicará la espectacularidad con que los narcos generan terror en la población [...]. La población trabajadora de la villa está tan aterrorizada que no reacciona, inmovilizada, 'de piedra”. Para un repaso de todas las Antígonas latinoamericanas, cf. Pianacci 2008: passim. 
En correspondencia con el autor y a la pregunta de por qué Antígona, Marán afirma:

En realidad todo nace de una noticia de un hecho policial sucedido en la Villa 1.11.14 de Bajo Flores. Un ajuste de cuentas entre dos bandas de traficantes de paco con ciertas similitudes al mito de Antígona. De allí que comienzo a escribir una versión que se sitúe en ese ambiente marginal, cuando la producción y comercialización de la droga pasa de la mano de traficantes nativos a narcos extranjeros (peruanos y paraguayos). En la mayoría de las reseñas periodísticas de la terrible realidad de los jóvenes muertos por el paco son siempre las madres, hermanas o novias que llevan la voz cantante y que denuncian estos hechos. Casi naturalmente aparece la figura de Antígona como mito para sostener la historia ${ }^{3}$.

Como explicita la indicación escénica, la obra sitúa la mítica Tebas en la villa del Bajo Flores, frente a la cancha de fútbol del club San Lorenzo en Buenos Aires. Actualmente los orígenes y las características de la villa han alertado el interés periodístico por los graves sucesos de violencia que trascienden. El lugar ha sido tomado literalmente por inmigrantes peruanos que trafican y promueven la prostitución.

El título metonímico menciona a Antígona por "villa". Ella representa acaso la consustanciación de las características de la villa: la marginalidad, la vida en riesgo permanente, al filo de la muerte. A propósito de los números 1-11-14, un vecino entrevistado afirma: "El que vivió en aquella villa, si no conoce las cuatro esquinas y las canillas, no vivió, te está mintiendo", es decir, las puertas representan una parte sustantiva de la comunidad de la villa. Podría deberse acaso a que en esas puertas se hallaban las canillas de las que la gente tenía acceso al agua corriente ${ }^{4}$. A modo de subtítulo el autor aclara que la representación será una versión libre de la creación sofoclea. La primera indicación escénica describe el espacio: una cocina llena de hollín con ollas mugrientas que se emplean para elaborar la pasta base de la cocaína. En un poste de luz inclinado cuelgan una madeja de cables y "tres pequeños cadáveres". El espectador moderno -como el de la antigüedad- también requiere la contemplación del "cómo" ocurrieron

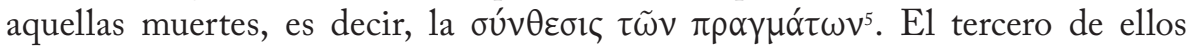
remite a "las tropas" de Polinices o los bandos que apoyaron a uno u otro jefe.

${ }^{3}$ A propósito de las manifestaciones de mujeres en los espacios públicos desde los comienzos del S. XX, cf. Saravia 1999 y 2007.

${ }^{4}$ Cf. solesdigital.com.ar/sociedad/historia_villas_2.htm "En respuesta a por qué 1-11-14, y aunque alguno piense también que quizá es una fecha, es simplemente la unión de las villas 1 la 11 y la 14. O por ejemplo la que está en la cancha de Huracán que es la Zavaleta, es la 2124-NHT Zavaleta, donde NHT Zavaleta fue un intento de barrio de tránsito para desarmar las villas, pero terminó siendo parte de esta”.

${ }^{5}$ En términos de Arist. Po. 1450 a 5. 
La obra está compuesta por 17 escenas, todas subtituladas.

La primera, a modo de prólogo, comienza con la presencia del cura villero ciego (Tiresias). Desde el principio queda establecido el itinerario dual de los habitantes: por un lado la gente solidaria que colaborará en la realización de los funerales; por el otro lado Creonte, los sicarios y los transas. El cura lo caracteriza: "Muertos los hermanos de Antígona te toca a vos hacerte cargo del negocio sucio de la villa”. Y continúa: “... estás asustado... Un cobarde que se muere de miedo por tener que ponerse al frente de la situación...” $(A: 2-3)^{6}$. Esta conducta señalada de resignación y obediencia emparienta al personaje con aquel de Anouilh?

Consciente de su desempeño, el cura se adjudica cierta capacidad de presagiar el futuro. Su poder surge de la observación, dado que, como él mismo manifiesta, las cosas tienden a repetirse, es decir, aplica el poder que otorga la experiencia. Finalmente el prólogo llega a su fin con la introducción de Hemón y Eurídice, que suscita reflexiones breves del cura. El hijo aparece apoyado en una computadora vieja y la madre sabe tejer como en la obra de Anouilh y también cocina remolachas, pero "hoy cocina la pasta del infierno y sus manos rayan la diabólica tiza con que se extermina a los jóvenes" (A: 3). Ella representa más una anti-madre dado que se invierte el papel de una madre "natural" positiva. Por último, el cura dice: "Bueno, esta es la tragedia de la 1.11.14. Me parece que están presentados todos los personajes" ( $A$ : 3 ). De modo que la personificación de "villa" por "Antígona" las identifica. La tragedia de Antígona representa a la población villera en su conjunto.

Aparecen los dos sicarios que atraviesan el halo de irrealidad en el que se mueven los demás personajes e incorporan la realidad, el mundo de las ¿apariencias? de Sófocles. Equivalen al Phylax o custodio sofocleo, o bien, a los tres Guardias en la obra de Anouilh. El cura los presenta como los brazos ejecutivos de Creón para el trabajo sucio. Forman una fuerza de choque y, para ellos, el mañana no existe, se rigen por la desesperanza sin futuro. En un diálogo de chanza comprobamos la inanidad en la que viven. Emplean un lenguaje soez y vulgar. El cura, a su modo, intenta inculcarles una dosis de esperanza, pero el lenguaje crudo de los sicarios evidencia la imposibilidad de intentar redimirse. E1 Sicario 1 repite frases como "Dios ha muerto", "El hombre ha muerto, "yo... nada...” (A: 4) que ratifican la carencia de alguna esperanza ${ }^{8}$.

${ }^{6}$ En adelante, abrevio $A$ para Antígona 1-11-14 del Bajo Flores. Para las citas de Sófocles sigo la edición de Pearson ${ }^{2} 1928$, las traducciones me pertenecen.

${ }^{7}$ De la correspondencia con el autor: "La influencia de Anouilh está muy presente. Después del texto clásico de Sófocles es la versión que más me gusta, y uno de mis textos favoritos. El contacto más cercano entre la Antígona de Anouilh y la mía es el personaje de Creonte, también cierto desenfado y el juego con los anacronismos". Además, la presentación de Ismena como "pizpireta" evoca el prólogo de J. Anouilh, en el que ella se comporta como la hermana halagada por su belleza, que se divierte y baila con Hemón.

${ }^{8}$ Enunciados ligados a la filosofía de Nietzsche en Así habló Zaratustra y de J.P. Sartre. 
Escena 2: "La Siam", ocupa la escena como signo de la época del primer peronismo y hasta la década del '60. Con velas en su interior, parece un altar'. Como signo teatral, la Siam recuerda las carcasas que emplea Griselda Gambaro en sus obras, como Antígona Furiosa (Creón-Corifeo) y en La Gracia, los tres armazones donde se hallan encerrados los personajes, símbolo de los efectos de la dictadura y de las aberrantes laceraciones humanas.

Las hermanas dialogan acerca de los espacios devastados por el ataque, y nos enteramos que los cadáveres que se ven en los cables corresponden a sus hermanos. Estos cuelgan tan corrompidos que no pueden reconocerse, como tampoco podían identificarse en la obra de Anouilh ${ }^{10}$. La muerte se produjo en un duelo y una vez que se mataron mutuamente los sicarios les patearon la cara hasta desfigurarlos. Antígona señala: "Nuestro tío decidió que este colgajo quedara sin ser enterrado, por atacar la villa de la mano de los extranjeros" ( $A$ : 8). Y continúa: "Aquí colgado, sin llanto ni tumba como un dulce botín para las ratas" ( $A$ : 9), ya no se mencionan las aves de rapiña o los canes, ni tampoco se refiere a él como un dulce tesoro para las aves de rapiña (S. Ant. 29-30) ${ }^{11}$. Los ritos fúnebres modernos para Etéocles consisten en tiros al aire y abundante cerveza.

Las hijas de Edipo aclaran, además, que Creonte ha prohibido enterrar al traidor. Antígona pide ayuda para bajar el cuerpo y sepultarlo, pues no hay hombres que lo hagan. La violencia de la villa se especifica un poco más cuando Antígona insinúa que Creón ha abusado de Ismena y pide que la televisión filme a aquel en su descaro ${ }^{12}$. Luego concluye que las mujeres pueden llevar armas, pasar tizas de cocaína por las fronteras, pero jamás podrían arriesgarse a desobedecer las órdenes "del macho" ( $A$ : 10).

Escena 3. "Ponchito de los pobres". Las imágenes del sol: "La más bella luz que jamás haya brillado en la 1-11-14, la de las tres puertas" transcriben los primeros tres versos de la párodos de Antigona (100-102). El nombre y los atributos de la villa traen reminiscencias de los epítetos épicos de Troya: "la bien amurallada", "la de amplias avenidas", "la de grandes puertas"13. Así también,

9 "La heladera Siam fue un símbolo del auge y devastación de la industria nacional, y en ese sentido al vaciar estas empresas nacionales llegó inevitablemente la desocupación, la falta de trabajo dañó mortalmente a varias generaciones y permitió el ingreso de la droga en los sectores más vulnerables, en su versión más siniestra y barata el paco". De la correspondencia con el autor.

${ }^{10}$ Cf. Saravia 2015: 59-75.

${ }^{11}$ Antígona tampoco lo nombra como kasigneton kara "hermano queridísimo", S. Ant. 899 y 915 .

${ }^{12}$ La presencia de mass-media otorga visos de puesta pos-moderna a la obra, cf. Bauzá 2003: 94-116. La intromisión de las lentes establecen un vaso comunicante entre la villa y la ciudad, posiblemente al modo de espejos deformantes.

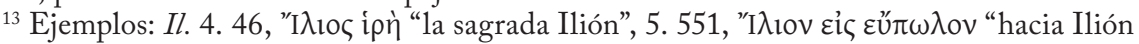

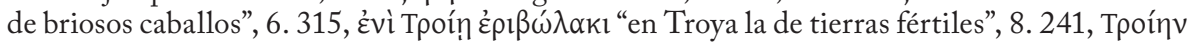

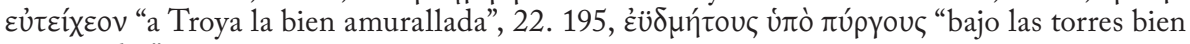
construidas". 
la entrada de Polinices en la villa se menciona en la misma escena "como un huracán de fuego" $(A: 11)^{14}$. Los símiles continúan, por ejemplo en la escena 6 , cuando Creonte ordena izar nuevamente el cadáver. Los comentarios del Sicario 2 en ese momento equivalen al ingreso del Guardián en Antígona (384 sqq.) y su perplejidad alcanza notas naturalistas: "Y el muerto que se resiste a ser izado, es como una bandera de plomo que no quiere flamear al viento" ( $A$ : 20).

La escena 4, "El sepelio", parece una escena hiper-realista. La música fúnebre que estalla en el ambiente de balacera es la cumbia y todo se convierte en un aquelarre de balas. En este momento Creonte promulga el edicto y el castigo al traidor. El sepelio festivo ejemplifica la contradicción radical propia del oxímoron, un rasgo estilístico del gusto de Sófocles.

En la escena 5, "La rayadura de la tiza", la familia de Creonte, Hemón y Eurídice, rayan la tiza y en la Escena 8 los sicarios, tan atemorizados como el Guardián en el Episodio I de Sófocles, no saben cómo explicar que el muerto ha descendido del poste. Como en el funeral simbólico en la obra del autor trágico, en esta pieza moderna se levanta un viento huracanado que instantáneamente cesa cuando se resuelve el conflicto.

Escena 7: "El sermón" en un humilde altar de la villa. El cura recita una versión modesta y escueta del Estásimo I de Antígona para finalizar con una pregunta retórica: “№ será hora de pararse de nuevo en dos patas y pedir perdón por tanta locura?” ( $A$ : 21) esta intervención funciona como un paréntesis entre las escenas contiguas.

En las Escenas centrales 8, 9 y 10: "El prendimiento", "El miedo" y "La hermana", los sicarios traen a Antígona cubierta con la capucha y esta lleva la faca que antes estaba clavada en el poste donde pendían los cadáveres. Creonte interpreta que aquel que puede empuñar el arma de Etéocles, como también defender a Polinices, esconde un criminal de los más peligrosos en cuanto administra, según la contingencia, la muerte de los dos bandos. Esta manera de pensar ejemplifica la capacidad del ser humano expuesta en el Estásimo previo y, en consecuencia, plasma el daimonion téras "el portento divino" como se describe a Antígona en Sófocles (376). Para Creonte, ella es capaz de "cruzar con total impunidad de un lado al otro del río" ( $A$ : 22). El Sicario 1 interpreta esta imagen literalmente y refiere la ubicación precisa del lugar donde la encontraron: cerca de la Canchita de los paraguayos, a punto de subirse al poste. Cuando le quitan la capucha, recién entonces descubren de quién se trataba. A continuación los sicarios se retiran suplicando por sus vidas y comienza el diálogo equivalente al episodio II de Sófocles. Nuevamente se insiste en que los hermanos han quedado irreconocibles. Asimismo se evoca la visión dual de la villa: junto con la gente sacrificada en el otro extremo, viven entre ellos los que se dedican a los

\footnotetext{
${ }^{14}$ A propósito de las metáforas que designan a Polinices, cf. Saravia 2011: 395-411.
} 
robos, el paco, la merca y los alquileres ilegales. Los hijos de Edipo se ubicaban en el segundo grupo. Ellos querían todo y un poco más para sí mismos. Creonte pretende solucionar el dilema con dinero: “Cuánta plata querés?” (A: 28). Y Antígona responde como la heroína de Sófocles (523) "No nací para compartir odio sino amor". Creonte levanta un panfleto y lee: "JJusticia por Polinices! Muerto en manos de los transas y sicarios de Creonte" (A: 29). Este incidente representa una manera gráfica de plasmar las voces disidentes que se levantan en disconformidad, como las menciona Hemón en el Episodio III (688-700). Creonte se enfurece y los Sicarios se llevan a Antígona. El gobernante ordena matar a las dos hermanas, e Ismena aparece como en el final del Episodio II. La condena decisiva se consumará en la cueva $(A: 31)$.

La escena 11, "E1 hijo", equivale al Episodio III de la obra clásica. El debate acerca del poder, que se instaura en aquel episodio, aparece como el discurso del dominio de la droga en la villa. Creón caracteriza a Edipo como un hombre honesto y solidario, que trabajaba en la fábrica Siam; asimismo vislumbra un riesgo porque la hija de Edipo tiene la misma mirada. Hemón pretende que el padre le ceda el negocio de la droga y que libere a su novia. Aquel rechaza los dos reclamos. Una vez más, el hijo se retira furioso ${ }^{15}$.

Escena 12. "Antígona va a la muerte". Tanto en Sófocles como en Anouilh, Antígona se despide de su ciudad y sus sueños. En este caso los sicarios la acompañan. El viento ejerce el poder de la corrupción, del ahogo. No hay aire en la villa, sólo viento ${ }^{16}$. La cueva, en medio de la villa pues no hay un borde más allá, estará representada con la heladera. Así como Edipo, en el éxodo de Edipo Rey, de padre dispensador llega a ser padre mendicante, la heladera deja de representar una época promisoria para finalizar como el habitáculo-caverna al que se somete a la joven.

Las escenas 13 y 14: "El arrepentimiento" y "El ciego y el sordo", componen la peripecia de la obra que Creón expresa así: "Estoy cansado, cura. No sé qué hacer" $(A: 38)^{17}$. En el diálogo entre este y el cura villero, se distinguen nuevamente los dos modos de vivir en la villa: la gente modesta que trabaja, con hijos que van a la canchita; y, mientras tanto, los soldados de Creonte venden "ese alquitrán". El cura refiere los comentarios negativos de la gente decente, que piensa matar a Creonte de un puntazo ${ }^{18}$. Y más aún, el Cura vaticina que alguna de las madres, que ven a sus hijos enajenados por

${ }^{15}$ El título de la escena recuerda el cuento homónimo de Horacio Quiroga. Ambos hijos mueren: el de Quiroga porque lo atrapa la selva o el padre cede a su hechizo; Hemón muere por la incomprensión y la perversidad de su padre que lo convierte en un obsesivo.

${ }^{16}$ Esta imagen drástica de que el viento todo sofoca a su paso tiene alguna reminiscencia con las imágenes finales de Cien años de Soledad y La Hojarasca, ambas de G. García Márquez. Asimismo más reciente se halla El viento que arrasa de Selva Almada (2012).

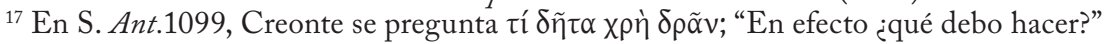

${ }^{18}$ Aflora "la dignidad de los nadie", como plasma Pino Solanas en su película homónima. 
el paco, lo matará. La desgracia se arraiga auditivamente con el viento que todo lo lleva.

Las instrucciones y los errores que se acentúan por los desajustes temporales coinciden en el cura y en Tiresias. Dirigiéndose al público, el cura explica ese error como en un aparte. Mientras se lleva a cabo el funeral, Antígona se ha colgado de una soga y produjo, a su vez, la muerte de Hemón.

Escenas 15 y 16. "La madre" y "La cueva" equivalen al éxodo de Antígona. Ambas escenas parecen un interludio lírico euripideo ${ }^{19}$. Eurídice, con un muñeco muerto en brazos, contempla a Polinices frente a la computadora. Luego Ismena refiere las muertes de la familia a modo de un relato de mensajero. Los sicarios apilan los cuerpos. Creonte se pregunta si es el que sigue en esta lista, al modo de un reconocimiento trágico. El estatismo de la escena se asemeja al ritmo staccato del Segundo mensajero en Antígona, absolutamente disonante con respecto al ritmo vertiginoso de los episodios anteriores.

A modo de epílogo, la escena 17 reza "Oración del cura villero". El cura recita un poema del padre Mugica y aparece su imagen en el proyector. El sicario 2 confiesa su nacionalidad como una vergüenza. Los personajes se ven como espectros nuevamente por efecto de la iluminación: Antígona es enfocada por la luz de la heladera, Ismena por su velador giratorio, Creonte pasa dibujitos animados, Hemón y Eurídice por el monitor de una computadora. El reflejo de la heladera se vuelve cegador y luego se produce un cortocircuito ${ }^{20}$. La escena final en la que hay una actitud de reverencia otorga el triunfo al Cura villeroTiresias ${ }^{21}$.

Creón finaliza inerme como un muerto en vida, superado por las circunstancias. Según el teatro de Artaud, Creón encarna aquello de los “cuerpos sin espíritu" ${ }^{2}$, pero mucho antes Sófocles lo había creado con la desesperación

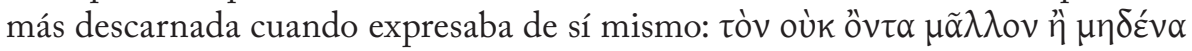
(1325) “... que no soy más que una nada”. El personaje a su vez adquiere notas del teatro del absurdo cuando, por ejemplo, no justifica establecer diferencias entre los hermanos. Para él, carece de sentido establecer méritos o matices. El prólogo metateatral tiene su antecedente en Antigone de Anouilh; no obstante, Marán lo propone con más sentido metafísico. La relación del hombre con los dioses en el final muestra un optimismo esperanzado, si la luz llega a ser auténtica, como deja sentir el silencio reverente de los hombres ${ }^{23}$.

\footnotetext{
${ }^{19}$ Cf. López Férez 1988: 389, Battezzato 2005: 153.

${ }^{20}$ Recuerda la luz que encandila a Teseo en Edipo en Colono (1648-1655), en el momento de la desaparición de Edipo.

${ }^{21}$ En términos de agón lógon el que finaliza la escena obtiene el triunfo. Cf. Duchemin 1968: 166 y passim. Así ocurre en la obra.

${ }^{22}$ Cf. Artaud 1938: passim.

${ }^{23}$ Recuerda la luz del Guernica de Picasso. Cf. Ramírez 1999: passim.
} 
Las pinceladas gruesas que modelan los claroscuros dramáticos otorgan profundidad metafísica a ese doble escenario: el cura villero-Tiresias y las sombras (de desconcierto y confusión) y las luces (la sensatez) la realidad, si bien es mostrada con sus quebrantos, trae la claridad del discernimiento, como en Áyax ${ }^{24}$. Así como en Áyax cada personaje relata su versión de los hechos en el amanecer, también en la obra de Marán varios personajes refieren el duelo entre los hermanos, como una recepción interna metateatral de la muerte, por caso Hemón, quien efectúa un racconto más del duelo entre ellos (Esc. 3) que en el prólogo había descripto el Cura villero y, más tarde, Antígona. La composición de los acontecimientos en mosaico abre líneas diversas de interpretación, se pone en ejercicio la subjetividad. La obra comienza con los espectros que se mueven como tales hasta que llegan los sicarios ${ }^{25}$. En el fin, el momento espectral permanece absolutamente estático (escenas 15 y 16).

La contaminación es representada por las ratas (por ej. Escena 2), una metáfora recurrente en la plástica moderna ${ }^{26}$, equivalente a la peste apolínea de Edipo Rey- y el sucedáneo de este fenómeno en Antígona se ve cuando el Guardián, todavía asombrado, relata el tifón que tapa la luz solar mientras se llevaba a cabo el funeral simbólico de Polinices (S. Ant. 415-421).

El Cura villero recita en la Escena 7 el equivalente al Estásimo I, con un pronunciado tono nostálgico por el sentido de adýnaton o imposibilidad de realizar la hazaña antropológica del hombre ${ }^{27}$. Menciona el "viento de la historia" ( $A$ : 21) en alusión a la civilización que el hombre ha sabido conquistar. Este motivo aparece, a su vez, en las escenas 3, 5 y 12: la muerte de Polinices, el intento del funeral y la muerte de Antígona anticipada en la despedida. Es decir, los vendavales sofocan a Polinices y Antígona. De este modo, las polaridades que inmortaliza el "Himno al hombre" de Antígona como esas de pantóporosáporos, mechané-améchanon y bypsipolis-ápolis permanecen intactas en el segundo término de las antítesis. Y como en la obra de Sófocles, aquellas potencialidades quedan reducidas, paradójicamente, al marasmo que proyecta el Estásimo IV por los casos de muertes forzadas, encierros y la falta de libertad, como una ironía respecto del primero 28 .

Los curas villeros tienen su homenaje en el personaje del Padre Mugica. Su

${ }^{24}$ El claroscuro convierte al teatro de Sófocles en precursor del barroco ya sea de Calderón, La vida es sueño, o Velázquez, Las meninas.

${ }^{25}$ Las escenas de las sombras fantasmales recuerdan vivamente aquellas de la épica homérica, por ejemplo Elpenor en $O d$. 11. 51 sqq., y Patroclo en Il. 23.65 sqq., como también la sombra de Darío en Los Persas de Esquilo (681 sqq.).

${ }^{26}$ Cf. Oliveras (2007: 158), quien afirma que las ratas connotan peste, corrupción, enfermedades y demás.

${ }^{27}$ Cf. Mc Loughlin 2009: 15: “... adynaton (in Latin, impossibilia), which can be defined as the expression of 'the impossibility of addressing oneself adequately to the topic'».

28 Seaford 1990: 76-90 y Saravia 2007: 96. 
vida se adentra en el reservorio mítico de las villas y la capital. No fue un hombre que soñara para sí sino que, impelido por una bonhomía magnánima, involucró a la sociedad con el impulso de sus sueños. La memoria colectiva le ha otorgado estatuto de héroe. Él resultó ser el artesano de la historia que se enlaza con la leyenda.

El coro en la tragedia ática representa un recorte de aquella sociedad que ha generado al héroe. Los coreutas, solidarios con el protagonista, llevan máscara e intervienen como un recurso moderador que informa o bien comenta la acción. Ellos expresan por edad y experiencias la sabiduría, la voz de la razón. La obra de Marán no incluye ningún canto coral, y podemos inferir que constituye un indicio más de la marginalidad social del espacio representado ${ }^{29}$.

El cadáver de Polinices y los demás aparecen colgados de los postes de luz, se señala con insistencia que se ven pequeños. En su lugar, esperaríamos que algún par de botines de fútbol o zapatillas pendieran de los cables de iluminación. Por los usos, costumbres, códigos o valores del ambiente marginal, estos marcarían el territorio como una delimitación de poder. Si lo vemos como "un colgajo" insignificante, como se menciona, la exposición de los cadáveresbotines imprime un signo inverso respecto de la creación de Sófocles ${ }^{30}$.

En el autor clásico, los despojos permanecen en las afueras de la ciudad ep' akron (S. Ant. 1197), pero la gravedad del hecho los vuelve en el espacio central, aunque evocado. En la obra moderna, los cuerpos se ven en un primer plano pero parecen lejanos, distantes. Ya no se trata de botines o zapatillas sino de toda la persona. La perspectiva que las contexturas insinúan no condice con la dimensión del conflicto que suscitan, ni con el plano de los personajes. Crea una poli-perspectiva -o doble perspectiva-, que conecta con el cubismo y el afán de mostrar al hombre deshecho. Asimismo, por el opuesto, el texto alcanza reminiscencias del teatro pos-moderno por la atención que demanda el cuerpo ${ }^{31}$. Podríamos considerarlos como títeres, por la lejanía y, por degradación, con cierto grado de metamorfosis. También puede interpretarse como el estado en que quedan los niños y jóvenes reducidos después del consumo de paco. Si desde el comienzo somos conscientes del desenlace, se debe a que el mito constituye un punto de partida común a todos en cuanto simplifica el sentido del referente. Nadie puede dudar en qué quiso decir el autor. Esta cohesión social que se instala en la audiencia también pertenece a los efectos de los relatos míticos ${ }^{32}$.

\footnotetext{
${ }^{29}$ Para el estudio de los coros en las tragedias de Sófocles, cf. Burton 1980: passim, Kitzinger 2012: 385-389, Murnaghan 2012: 224-225.

${ }^{30}$ Lo mismo ocurre con el personaje de Eurídice que cocina el paco, no representa a las madres que sufren por sus hijos, no representa a una madre nutriente sino exterminadora de hijos. El estatismo de la escena donde aparece por última vez sugiere otros sentimientos.

${ }^{31}$ Cf. Geis 1994: 29-44 y Pavis 1998: 207-223.

${ }^{32}$ Para los efectos de la recepción, cf. Budelmann y Haubold 2008: 16-18 y Biglieri 2014: passim.
} 


\section{Conclusiones}

Que el espacio de la Tebas-Atenas se sitúe en una villa miseria de la capital de Argentina se convierte en sí mismo en un acto de denuncia contra la violencia que castiga a los habitantes del predio ${ }^{33}$. La guerra de narcos recrudece en la Villa 1-11-14, a pocos pasos de la vida cotidiana de Buenos Aires, una de las capitales más importantes del mundo. La inercia y la desidia ante la corrupción de uno y otro lado de la villa acaso representan una consecuencia del ojo creóntico -omma deinón (S. Ant. 690)-que deja perplejos o helados a los habitantes ${ }^{34}$.

La violencia, como modo de vida cotidiano, corrobora la disolución de los valores y una ruptura del entramado social. En las Antígonas, el que ostenta una conducta frenética cree que puede dominar todas las situaciones y tampoco atisba que exista alguna alternativa más allá de sus ocurrencias. Esta obsesión, que se desmadra en el ejercicio del poder, arroja a los personajes fuera del marco institucional y los convierte en esperpentos ${ }^{35}$.

La gran ciudad alberga el ergon -lo central, la norma- y también el parergon -lo marginal, anómico- áreas hegemónicas y áreas periféricas ${ }^{36}$. Marán enfoca el conflicto social en la periferia -tanto víctimas como victimarios del narcotráfico-, las zonas de los bordes o fronteras, no sólo físicos, sino también metafísicos. El dramaturgo subraya la contradicción de la vida en la capital. Nos interpela con el lenguaje cifrado del mito y del arte dramático y nos reclama que no miremos para otro lado una vez más. La obra se identifica con el expresionismo en cuanto movimiento contestatario del realismo ${ }^{37}$. $\mathrm{El}$ autor muestra con aplastante sencillez la ruptura del entramado social y, en ese sentido, su estética se acerca a los "canónicos" ismos de vanguardia, valga el oxímoron. Asimismo, la reflexión que produce el foco del conflicto en la ciudad constituye una indagación propia del surrealismo ${ }^{38}$. La villa se puebla con diversidad de comunidades: peruanos,

${ }^{33}$ Sobre el tópico del espacio Tebas-Atenas, cf. Zeitlin 1990: 144.

${ }^{34}$ A propósito de estos conceptos en relación con el surrealismo cf. Pempeu 2006: 267-277. Saravia 2014: en prensa. Recordamos una vez más que se denomina téras también a la cabeza de la gorgona y, en ese sentido negativo, Creonte actúa como tal; su poder deja duros a todos. El efecto de esta conducta puede asimilarse al panóptico de Foucault 2002: passim.

${ }_{35}$ El Estásimo II de Edipo Rey 873 define taxativamente la desmesura o býbris de los

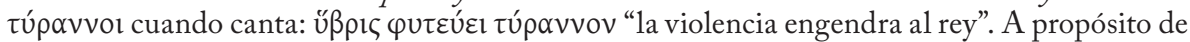
la metamorfosis que ocasiona el poder, Valle Inclán lo ejemplifica en Los esperpentos (1920). Cf. Rosenmeyer 1993: 569 sobre el desprecio de los límites que crea hombres injustos.

${ }^{36}$ Cf. Oliveras 2007: 158.

${ }^{37}$ Cf. Dubatti 2009: 132, quien afirma que el expresionismo es un antecedente de los “ismos". El movimiento trata de recordar lo humano en un mundo des-humanizado, y de denunciar el horror, reclamar el cambio, gritar el dolor.

${ }^{38}$ Cf. Pijoán-Gaya Nuño 1967: passim, Hedges 1983: 275-295 y Saravia 2014b en prensa. Por ejemplo artistas como Klee, Xul Solar, Testa, Domínguez, han enfatizado la visión de las ciudades. La Antígona 1-11-14 presenta un conflicto candente para el que no hay asomo de mejora, dado que no se trata de una guerra formalmente declarada, sino entre carteles que 
paraguayos, bolivianos, además de los argentinos del interior y otros, donde se oyen las voces anónimas que vigorizan el multiculturalismo. La bandera polícroma de las comunidades simboliza esa realidad ${ }^{39}$.

se disputan entre sí el dominio absoluto del mercado clandestino. Este modo de la guerra o guerrilla socava los cimientos de la sociedad en su población más vulnerable.

${ }^{39}$ Un manojo de experiencias entrecruzadas y entretejidas, en las que se combinan diferentes tonalidades y texturas es como la bandera del Tawantinsuyo, hecha con trozos de telas de distintos colores, señaló Emma, una vecina boliviana que asoció la recopilación de testimonios con el emblema de los pueblos del altiplano, confeccionado con cuadraditos de colores que reproducen los matices del arco iris. Y Tawantinsuyo, que es un nombre compuesto, proviene de las voces quechuas "tawa": cuatro y "suyo": nación o estado, lo que significaría desde lo idiomático, un todo que tiene cuatro naciones. File: cronista33 Historiavilla\%201-11-14pdf 


\section{Edición de TeXtos}

Anouilh, J. (1947), Antigone. Paris: La Table Ronde.

Butcher, S. H. (41951), Aristotle's Theory of Poetry and Fine Art. New York: Dover Publications.

Collard, Ch. (2008), Aeschylus: Persians and Other Plays. Oxford: University Press.

Dawe, R. D. (ed.) (1982), Sophocles. Oedipus Rex. Cambridge: University Press.

Marán, M. (2014), Antígona 1-11-14 del Bajo Flores. Versión libre sobre Antígona de Sófocles. Mar del Plata: inédita.

Munro, D. B., Allen, T. W. (31920), Homeri. Opera. T. I, II, III, IV. Oxford: University Press.

Nietzsche, F. Así habló Zaratustra. (Primera edición en alemán 1883), edición digital www. Infotematica.com.ar

Pearson, A. C. (ed.) (1928), Sophoclis, Fabulae. Oxford: Oxford University Press.

Saravia, M. I. (2012), Antígona. Sófocles. Traducción, notas y estudio preliminar. La Plata: Edulp.

Bibliografía de consulta

Artaud, A. http://www.revistalavoragine.com.ar/revista2/ARTICULOS/ Artaud\%20-\%20E1\%20teatro\%20y\%20su\%20doble.

Battezzato, L. (2005), "Lyric”, in Gregory, J. (ed.), A Companion to Greek Tragedy. Oxford, Blackwell: 149-166.

Bauzá, H. (2003), "La Posmodernidad en el Teatro", in Dubatti, J. (ed.), De los dioses hindúes a Bob Wilson. Buenos Aires, Editorial Atuel: 94-116.

Biglieri, A. (2014), Curso "Recepción e historicidad", impartido en la Facultad de Humanidades. UNLP: Inédito.

Budelmann, F., Haubold, J. (2008), "Reception and Tradition", in Hardwick, L. and Stray, C. (Eds.), A Companion to Classical Receptions. Oxford, Blackwell: 13-25.

Burton, R. W. B. (1980), The Chorus in Sophocles' Tragedies. Oxford: Clarendon Press.

Cronista Mayor de Buenos Aires. Año 4, Agosto 2002, Buenos Aires. File: cronista33Historiavilla\%201-11-14pdf.

De Micheli, M. (1999), Las Vanguardias Artísticas del Siglo XX. Madrid: Alianza.

Dubatti, J. (2009), Concepciones del Teatro. Poéticas Teatrales y Bases Epistemológicas. Buenos Aires: Colihue.

Dubatti, J. (2014), "Crítica de Antígona 1-11-14 del Bajo Flores, de Marcelo Marán” enhttp://tiempoargentino.com/nota/140817/ 
una-notable-reescritura-de-sofocles-en-mar-del-plata

Duchemin, J. (1968), L’AГSN dans la Tragédie Grecque. Paris: Les Belles Lettres.

Foucault, M. (2002), Vigilar y castigar. Nacimiento de la prisión (Primera edición en francés: 1975). Buenos Aires: Siglo XXI.

Geis, D. R. (1994), Postmodern Theatric[k]s. Michigan, Ann Arbor: University Press.

Hedges, I. (1983), "Surrealistic Metaphor: Frame Theory and Componential Analysis”, Poetics Today 2 Metaphor: 275-295.

Kitzinger, R. (2012), "Sophoclean Choruses”, in Markantonatos, A. (ed.), Brill's Companion to Sophocles. Leiden, Boston, Brill: 385-407.

López Férez, J. A. (1988), Historia de la literatura griega, Madrid: Ediciones Cátedra.

Mc Loughlin, K. (2009), "War and words", in Mc Loughlin, K. (ed.), The Cambridge Companion to War Writing. Cambridge, University Press: 1524.

Murnaghan, S. (2012), “Sophocles' Choruses”, in Ormand, K. (ed.), A Companion to Sophocles. Oxford, Blackwell Publishing: 220-235.

Nelli, F. (2012), "Usted está aquí: Antigone against the Standardization of Violence in Contemporary Mexico", Romance Quarterly 59. 1: 55-65.

Oliveras, E. (2007), La metáfora en el arte. Retórica y filosofía de la imagen. Buenos Aires: Emecé.

Pavis, P. (1998), "Voces e Imágenes de la escena", in La Herencia Clásica del teatro Postmoderno. Santiago, Editorial Lom: 207-223.

Pempeu, F. P. (2006), "A mitología y el surrealismo: Nadya, la musa-ménade de André Breton", in Vilar de Lima, M., Araujo, O. L. (org.), Ensayos em Estudos Clássicos. Campina Grande, EDUFCG: 267-277.

Pianacci, R. E. (2008), Antígona: Una tragedia Latinoamericana. Irvine, California: Ediciones de Gestos.

Pijoán, J., Gaya Nuño, J. (1967), Summa Artis. Historia General del Arte. Vol. XXIII, Madrid: Espasa-Calpe, S.A.

Ramírez, J. A. (1999), Guernica. Madrid: Electra.

Rosenmeyer, T. G. (1993), "Elusory Voices: Thoughts about the Sophoclean Chorus", in Rosen R., Farrell J. (eds.), Nomodeiktes: Greek Studies in Honor of Martin Ostwald. Ann Arbor: University of Michigan Press.

Saravia de Grossi, M. I. (1999), "Electra de Sófocles, una interpretación", Synthesis 6: 99-114.

Saravia de Grossi, M. I. (2007), Sófocles. Una interpretación de sus tragedias. La Plata: EDULP. 
Saravia de Grossi, M. I. (2011), "Las metáforas de la guerra en Antígona de Sófocles", in Galán, L. M., Buisel, M. D. (comp. and ed.), Itinera, Homenaje al Dr. Alberto J. Vaccaro. La Plata, Al margen: 395-411.

Saravia de Grossi, M. I. (2014a), «Las expresiones de violencia en Antigona y Edipo Rey de Sófocles». Revista Cartapacio, sección Conferencias y Disertaciones. Con comité de evaluadores, vol. no 25 ISSN 1850-0722 www.cartapacio.edu.arhttp://www.cartapacio.edu.ar/ojs/index.php/ctp/ article/view/1462

Saravia de Grossi, M. I. (2014b), "Daimónion téras, Antígona v. 376”. Actas de las $V$ Jornadas de Reflexión Monstruos y Monstruosidades. Buenos Aires: UBA. En prensa.

Saravia de Grossi, M. I. (2015), "Antígona de Jean Anouilh. Convergencias y divergencias desde el punto de vista de la obra de Sófocles", Circe 19: 5975.

Seaford, R. (1990), “The Imprisonment of Women in Greek Tragedy", JHS 110: 76-90.

Zeitlin, F. (1990), "Thebes: Theater of Self and Society in Athenian Drama", in Winkler, J. J., Zeitlin, F. (eds.), Nothing to do with Dionysus? Athenian Drama in its Social Context. Princeton, University Press: 130-167. 